\title{
PEMODELAN REGRESI SPASIAL INVESTASI LUAR NEGERI YANG MASUK KE INDONESIA
}

\section{Modeling of Foreign Investment in Indonesia Using Spatial Regression}

\author{
Muktar Redy Susila ${ }^{1 *}$, Rizfanni Cahya Putri ${ }^{2}$, Dian Arini ${ }^{3}$ \\ Sekolah Tinggi Ilmu Ekonomi Indonesia (STIESIA) Surabaya \\ Jln. Menur Pumpungan 30, Surabaya, 60118, Indonesia \\ e-mail: 1* muktarredysusila@stiesia.ac.id ; 2 rizfannicahyaputri@stiesia.ac.id ; \\ 3dianarini@stiesia.ac.id \\ Corresponding author*
}

\begin{abstract}
Abstrak
Salah satu faktor yang penting dalam perekonomian negara yaitu investasi penanaman modal. Menurut dari sumbernya investasi penanaman modal dibagi menjadi dua yaitu investasi penanaman modal dari luar negeri dan investasi penanaman dalam negeri. Banyak manfaat dari investasi penanaman modal dari luar negeri. Manfaat tersebut yaitu seperti untuk pembangunan, penyerapan tenaga kerja, pemasukan pajak, menambah devisa, perdagangan internasional, mempererat persahabatan dengan negara asing dan masih banyak lagi. Tujuan dari penelitian ini yaitu memodelkan investasi yang masuk ke Indonesia menggunakan model regresi spasial. Variabel prediktor yang digunakan yaitu jumlah angkatan kerja dan besar upah/gaji bersih bulanan. Berdasarkan hasil analisa penelitian didapatkan informasi bahwa Provinsi Jawa Barat merupakan provinsi yang paling tinggi mendapatkan dana investasi dari luar negeri. Untuk besar upah/gaji bersih bulanan tertinggi di Indonesia yaitu provinsi DKI Jakarta. Jumlah angkatan kerja yang paling tinggi di Indonesia adalah Provinsi Jawa Barat. Berdasarkan hasil uji Lagrange Multiplier yang menunjukan Lagrange Multiplier (lag) signifikan dengan nilai $\mathrm{p}$-value $<\alpha=5 \%$. Artinya bahwa untuk jumlah angkatan kerja, besar upah/gaji bersih bulanan, dan jumlah investasi pemodalan luar negeri antar provinsi di Indonesia terdapat dependensi spasial antar provinsi. Berdasarkan model regresi spasial yang diperoleh menunjukan bahwa jumlah angkatan kerja, besar upah/gaji bersih bulanan, dan pembobot wilayah berpengaruh signifikan terhadap jumlah investasi pemodalan luar negeri antar provinsi di Indonesia.
\end{abstract}

Kata Kunci : Investasi luar negeri, Regresi, Spasial.

\begin{abstract}
One of the important factors in the growth of a country's economy is investment. Sources of investment are divided into two, namely foreign investment and domestic investment. There are many benefits of foreign investment. These benefits are such as for development, employment, tax revenue, increasing foreign exchange, international trade, strengthening friendship with foreign countries and much more. The purpose of this research is to modeling of foreign investment in Indonesia using spatial regression. The predictor variables used are the number of labor and the net monthly salary. Based on the results of research analysis obtained information that the West Java province is the highest province to get investment funds from abroad. The highest net monthly salary in Indonesia is DKI Jakarta province. The highest number of labor in Indonesia is West Java Province. Based on the results of the Lagrange Multiplier test which showed a significant Lagrange Multiplier (lag) with a p-value $<\alpha=5 \%$. That's shows for the number of labor, the net monthly salary, and the foreign investment in Indonesia fulfill the spatial dependencies assumption. Based on the spatial regression model shows the number of labor, the net monthly salary, and the weighting has a significant impact on foreign investment in Indonesia.
\end{abstract}

Keywords: foreign investment, regression, spatial. 


\section{PENDAHULUAN}

Salah satu faktor yang penting dalam pertumbuhan suatu perekonomian negara yaitu investasi penanaman modal. Menurut dari sumbernya investasi penanaman modal dibagi menjadi dua yaitu investasi penanaman modal dari luar negeri dan investasi penanaman dalam negeri. Menurut data Badan Pusat Statistik (BPS) tahun 2019, pada tahun 2017 jumlah investasi penanaman modal luar negeri hampir dua kali dari jumlah penanaman modal dalam negeri [1].

Banyak manfaat dari investasi penanaman modal dari luar negeri. Manfaat tersebut yaitu seperti untuk pembangunan, penyerapan tenaga kerja, pemasukan pajak, menambah devisa, perdagangan internasional, mempererat persahabatan dengan negara asing dan masih banyak lagi. Menurut data BPS tahun 2015 hingga tahun 2019, investasi penanaman modal dari luar negeri menunjukan tren naik. Tren naik tersebut diikuti dengan kenaikan jumlah angkatan kerja di berbagai wilayah Indonesia. Pada tahun 2015 jumlah angkatan kerja di Indonesia yaitu 122.380.021 dan naik menjadi 131.005.641 pada tahun 2018 [2].

Menurut Sukirno [3] terdapat dua pendekatan dalam hal pengambilan keputusan dalam investasi. Kedua pendekatan tersebut yaitu pendekatan nilai sekarang dan pendekatan tingkat pengembalian modal. Pendekatan nilai sekarang yaitu pendapatan neto selama objek investasi tersebut berlangsung. Untuk pendekatan tingkat pengembalian modal yaitu bentuk persentase hasil pembagian investasi terhadap modal yang sudah diberikan. Untuk mendapatkan hasil yang optimal dari investasi tersebut dipengaruhi banyak faktor. Investasi sendiri merupakan suatu hasil dari pengembangan modal. Di dalam proses pengembangan modal tersebut dibutuhkan beberapa inputan. Misalnya dalam kasus makro ekonomi input yang digunakan yaitu sumber daya manusia, sumber daya alam, biaya, dan masih banyak lainnya. Kualitas dari input tersebut dapat mempengaruhi hasil investasi.

Hasil investasi suatu wilayah diduga dipengaruhi wilayah disekitarnya. Sehingga investasi yang masuk disuatu wilayah diduga dipengaruhi wilayah lainnya juga. Sebagai contoh wilayah Ibukota Jakarta mendapatkan investasi yang besar dan berdampak pada kota disekelilingnya seperti Bogor, Depok, Tangerang, dan Bekasi. Diduga investasi yang masuk di tingkat provinsi dipengaruhi oleh provinsi lainnya.

Adapun penelitian sebelumnya mengenai investasi luar negeri di Indonesia yaitu Ambarsari dan Purnomo pada tahun 2005 [4]. Di dalam penelitian mereka dikaji faktor-faktor yang mempengaruhi investasi luar negeri. Akan tetapi di dalam penelitian mereka belum memperhatikan pengaruh secara geospasial wilayah Indonesia. Selanjutanya yaitu Dewi dan Triyarti pada tahun 2015 [5] meneliti mengenai pengaruh pertumbuhan ekonomi, suku bunga, dan pajak terhadap investasi luar negeri di Indonesia. Pada penelitian mereka belum mengkaji mengenai faktor sumber daya manusia, biaya tenaga kerja dan kondisi geospasial di Indonesia.

Regresi spasial merupakan perkembangan dari model regresi. Perbedaan regresi spasial yaitu mempertimbangkan keterkaitan antar wilayah di dalam pemodelannya. Menurut Anselin dkk. [6] besar keterkaitan wilayah dipengaruhi oleh pembobot wilayah. Dalam pemodelan regresi spasial diperlukan uji dependensi spasial untuk mengetahui signifikasi pengaruh antar wilayah. Apabila ada dependensi antar wilayah maka layak untuk dilakukan pemodelan secara spasial. Terdapat tiga model dari regresi spasial. Model yang pertama yaitu Spatial Autoregressive Moving Average (SARMA). Model SARMA merupakan model regresi spasial yang melibatkan spasial lag variabel prediktor dan spasial lag pada error. Model yang kedua yaitu Spatial Autoregressive Model (SAR). Model SAR merupakan model regresi spasial yang melibatkan spasial lag variabel prediktor dan tidak melibatkan spasial lag pada error. Model yang ketiga yaitu Spatial Error Model (SEM). Model SEM merupakan model regresi spasial yang tidak melibatkan spasial lag variabel prediktor dan melibatkan spasial lag pada error. Untuk menentukan model regresi spasial yang sesuai bisa menggunakan uji Lagrange Multiplier.

Sesuai uraian di atas, penelitian ini bertujuan untuk mengetahui hubungan faktor sumber daya manusia dan biaya tenaga kerja terhadap investasi permodalan luar negeri yang masuk ke Indonesia. Diduga jumlah angkatan kerja dan upah pekerja mepengaruhi investasi pemodalan luar negeri yang masuk. Selain itu juga, diduga jumlah investasi pemodalan luar negeri yang masuk antar provisi di Indonesia saling berkaitan antara wilayah satu dengan wilayah lainnya. Untuk wilayah penelitian ini mencakup 34 provinsi. Oleh sebab itu dilakukan pemodelan regresi spasial untuk menjawab tujuan dari penelitian.

\section{METODE PENELITIAN}




\subsection{Sumber Data}

Data yang digunakan merupakan data sekunder yang diambil dari web BPS Indonesia yaitu www.bps.go.id. Data yang digunakan yaitu Jumlah Investasi Penanaman Modal Luar Negeri tahun 2017 merupakan variabel respon dan Upah/Gaji Bersih Bulanan serta Jumlah Angkatan Kerja pada tahun 2017 sebagai variabel prediktor.

\subsection{Variabel Penelitian}

Berikut difinisi dari variabel penelitian yang digunakan:

1. Jumlah Investasi Penanaman Modal Luar Negeri

Merupakan banyaknya jumlah investasi penanaman modal yang berasal dari luar negeri. Variabel tersebut merupakan variabel respon yang disimbolkan dengan $Y_{i}$.

2. Upah/Gaji Bersih Bulanan

Merupakan penerimaan buruh/karyawan berupa uang atau barang yang dibayarkan perusahaan/kantor/majikan tersebut. Penerimaan dalam bentuk barang dinilai dengan harga setempat. Penerimaan bersih yang dimaksud tersebut adalah setelah dikurangi dengan potongan-potongan iuran wajib pajak penghasilan dan lain-lain. Variabel Upah/Gaji Bersih Bulanan merupakan variabel prediktor dan dilambangkan dengan $X_{1, i}$.

3. Jumlah Angkatan Kerja

Merupakan penduduk usia produktif/usia kerja 15 tahun ke atas yang bekerja, punya pekerjaan namun sementara tidak bekerja, dan pengangguran (unemployment). Variabel Angkatan Kerja merupakan variabel prediktor dan dilambangkan dengan $X_{2, i}$.

Tabel 1. Struktur Data Penelitian

\begin{tabular}{|c|c|c|c|}
\hline No $(i)$ & Provinsi & $\begin{array}{c}\text { Variabel Prediktor }\left(X_{1, i},\right. \\
\left.X_{2, i}\right)\end{array}$ & $\begin{array}{c}\text { Variabel Respon } \\
\left(Y_{i}\right) \\
\end{array}$ \\
\hline 1 & Aceh & $X_{p, 1}$ & $Y_{1}$ \\
\hline 2 & Bali & $X_{p, 2}$ & $Y_{2}$ \\
\hline 3 & Bangka-Belitung & $X_{p, 3}$ & $Y_{3}$ \\
\hline 4 & Banten & $X_{p, 4}$ & $Y_{4}$ \\
\hline 5 & Bengkulu & $X_{p, 5}$ & $Y_{5}$ \\
\hline 6 & Gorontalo & $X_{p, 6}$ & $Y_{6}$ \\
\hline 7 & Irian Jaya Barat & $X_{p, 7}$ & $Y_{7}$ \\
\hline 8 & Jakarta Raya & $X_{p, 8}$ & $Y_{8}$ \\
\hline 9 & Jambi & $X_{p, 9}$ & $Y_{9}$ \\
\hline 10 & Jawa Barat & $X_{p, 10}$ & $Y_{10}$ \\
\hline 11 & Jawa Tengah & $X_{p, 11}$ & $Y_{11}$ \\
\hline 12 & Jawa Timur & $X_{p, 12}$ & $Y_{12}$ \\
\hline 13 & Kalimantan Barat & $X_{p, 13}$ & $Y_{13}$ \\
\hline 14 & Kalimantan Selatan & $X_{p, 14}$ & $Y_{14}$ \\
\hline 15 & Kalimantan Tengah & $X_{p, 15}$ & $Y_{15}$ \\
\hline 16 & Kalimantan Timur & $X_{p, 16}$ & $Y_{16}$ \\
\hline 17 & Kalimantan Utara & $X_{p, 17}$ & $Y_{17}$ \\
\hline 18 & Kepulauan Riau & $X_{p, 18}$ & $Y_{18}$ \\
\hline 19 & Lampung & $X_{p, 19}$ & $Y_{19}$ \\
\hline 20 & Maluku Utara & $X_{p, 20}$ & $Y_{20}$ \\
\hline 21 & Maluku & $X_{p, 21}$ & $Y_{21}$ \\
\hline 22 & Nusa Tenggara Barat & $X_{p, 22}$ & $Y_{22}$ \\
\hline 23 & Nusa Tenggara Timur & $X_{p, 23}$ & $Y_{23}$ \\
\hline 24 & Papua & $X_{p, 24}$ & $Y_{24}$ \\
\hline 25 & Riau & $X_{p, 25}$ & $Y_{25}$ \\
\hline 26 & Sulawesi Barat & $X_{p, 26}$ & $Y_{26}$ \\
\hline 27 & Sulawesi Selatan & $X_{p, 27}$ & $Y_{27}$ \\
\hline 28 & Sulawesi Tengah & $X_{p, 28}$ & $Y_{28}$ \\
\hline No $(i)$ & Provinsi & $\begin{array}{c}\text { Variabel Prediktor }\left(X_{1, i},\right. \\
\left.X_{2, i}\right)\end{array}$ & $\begin{array}{c}\text { Variabel Respon } \\
\left(Y_{i}\right)\end{array}$ \\
\hline
\end{tabular}




\begin{tabular}{llll}
\hline 29 & Sulawesi Tenggara & $X_{p, 29}$ & $Y_{29}$ \\
\hline 30 & Sulawesi Utara & $X_{p, 30}$ & $Y_{30}$ \\
\hline 31 & Sumatera Barat & $X_{p, 31}$ & $Y_{31}$ \\
\hline 32 & Sumatera Selatan & $X_{p, 32}$ & $Y_{32}$ \\
\hline 33 & Sumatera Utara & $X_{p, 33}$ & $Y_{33}$ \\
\hline 34 & Yogyakarta & $X_{p, 34}$ & $Y_{34}$ \\
\hline
\end{tabular}

Pada Tabel $1, p$ merupakan banyaknya variabel prediktor. Untuk nilai $p$ yaitu 1 dan 2 . Banyaknya observasi penelitian yaitu sebanyak 34 . Nominal tersebut menyesuaikan dengan banyaknya provinsi di Indonesia pada tahun 2017.

\subsection{Langkah Analisis Penelitian}

Langkah-langkah analisis yang dilakukan dalam penelitian ini adalah sebagai berikut:

1. Mendiskripsikan data Upah/Gaji Bersih Bulanan, Jumlah Angkatan Kerja, dan Jumlah Investasi Penanaman Modal Luar Negeri. Umumnya perhitungan yang digunakan dalam analisa statistik deskriptif yaitu rata-rata dan varians. Menurut Walpole dan Myers [7], Persamaan (1) merupakan persamaan untuk mencari rata-rata dan Persamaan (2) digunakan untuk mencari varians. Dilihat sekilas Persamaan (2) merupakan simpangan data terhadap rata-rata.

$$
\begin{aligned}
\bar{Y} & =\frac{\sum_{i=1}^{n} Y_{i}}{n} \operatorname{dan} \bar{X}=\frac{\sum_{i=1}^{n} X_{i}}{n} \\
s_{Y}^{2} & =\frac{\sum_{i=1}^{n}\left(Y_{i}-\bar{Y}\right)^{2}}{n-1} \text { dan } s_{X}^{2}=\frac{\sum_{i=1}^{n}\left(X_{i}-\bar{X}\right)^{2}}{n-1}
\end{aligned}
$$

dengan

$$
\begin{aligned}
& \bar{Y}=\text { rata-rata variabel respon } \\
& \bar{X}=\text { rata-rata variabel prediktor } \\
& s_{Y}^{2}=\text { varians varibel respon } \\
& s_{X}^{2}=\text { varians varibel prediktor } \\
& n=\text { banyaknya data } \\
& Y_{i}=\text { data variabel respon ke- } i \\
& X_{i}=\text { data variabel prediktor ke }-i
\end{aligned}
$$

2. Melakukan pemodelan regresi spasial:

a. Sebelum melakukan pemodelan regresi spasial dilakukan pemodelan regresi linier berganda. Persamaan regresi linier berganda ditunjukan oleh Persamaan (3).

$$
Y_{i}=\beta_{0}+\beta_{1} X_{1 i}+\beta_{2} X_{2 i}+\varepsilon_{i}
$$

dengan

$$
\begin{array}{ll}
\beta_{0} & =\text { konstanta } \\
\beta_{1} \text { dan } \beta_{2} & =\text { parameter dari variabel prediktor } 1 \text { dan } 2 \\
\varepsilon_{i} & =\text { error } \text { ke- } i[8] .
\end{array}
$$

b. Melakukan uji signifikasi parameter model regresi linier berganda. Parameter dikatakan signifikan apabila nilai $p$-value lebih kecil dari $\alpha$ yang besarnya ditentukan oleh peneliti. Menurut Draper dan Smith [9] estimasi parameter model regresi linier berganda dapat dicari dengan persamaan berikut:

$$
\widehat{\boldsymbol{\beta}}=\left(\boldsymbol{X}^{\prime} \boldsymbol{X}\right)^{-1} \boldsymbol{X}^{\prime} \boldsymbol{Y}
$$

dengan

$\widehat{\boldsymbol{\beta}}=$ matriks parameter

$\boldsymbol{X}=$ matriks variabel prediktor

$\boldsymbol{Y}=$ matriks variabel respon.

Untuk mengetahui signifikasi parameter dari model regresi linier berganda maka dilakukan pengujian. Berikut hipotesa dari pengujian signifikasi parameter secara serentak:

$H_{0}: \beta_{1}=\beta_{2}=0$ 
$H_{1}$ : minimal terdapat satu $\beta_{1}$ atau $\beta_{2} \neq 0$

Statistik uji yang digunakan [10]:

$$
\text { Fhitung }=\frac{\frac{\sum_{i=1}^{n}\left(\widehat{Y}_{i}-\bar{Y}\right)^{2}}{p-1}}{\frac{\sum_{i=1}^{n}\left(Y_{i}-\widehat{Y}_{i}\right)^{2}}{n-p}}
$$

Jika nilai Fhitung $>\mathrm{F}_{\text {tabel }(\mathrm{p}-1, \mathrm{n}-1,1, \alpha)}$ maka tolak $H_{0}$, sehingga dapat disimpulkan ada beberapa parameter signifikan terhadap model. Sedangkan untuk pengujian parameter secara parsial yaitu sebagai berikut:

$H_{0}: \beta_{p}=0$

$H_{1}: \beta_{p} \neq 0$

Statistik uji yang digunakan [11]:

$$
t_{\text {hitung }}=\frac{\beta_{p}-\beta_{0}}{\sqrt{\text { varians }\left(\beta_{p}\right)}}
$$

Jika nilai $t_{\text {hitung }}>t_{\text {tabel }}\left(\frac{\alpha}{2}, n-p\right)$ atau $t_{\text {hitung }}<-t_{\text {tabel }}\left(\frac{\alpha}{2}, n-p\right)$ maka tolak $H_{0}$, sehingga dapat disimpulkan parameter signifikan terhadap model.

c. Memeriksa asumsi multikolinieritas dan asumsi error memenuhi indentik, independen, dan berdistribusi normal (IIDN). Model dikatakan bebas dari kasus multikolinieritas apabila nilai VIF setiap variabel prediktor < 10 [12]. Menurut Draper dan Smith untuk uji dependensi error dapat digunakan uji Durbin Watson. Berikut langkah-langkah uji Durbin Watson:

$H_{0}:$ error independen (tidak ada kasus autokorelasi)

$H_{1}$ : error dependen (terjadi kasus autokorelasi)

Statistik uji:

$$
d=\frac{\sum_{i=2}^{n}\left(\varepsilon_{i}-\varepsilon_{i-1}\right)}{\sum_{i=1}^{n} \varepsilon_{i}^{2}}
$$

Untuk menentukan kriteria dependensi bisa digunakan batas atas (dU) dan batas bawah (dL). Nilai batas atas (dU) dan batas bawah (dL) dapat dilihat pada tabel uji Durbin Watson. Berikut kriteria dari uji Durbin Watson:

Tabel 2. Kriteria Uji Durbin Watson

\begin{tabular}{lc}
\hline \multicolumn{1}{c}{ Kriteria } & Hasil \\
\hline $0<\mathrm{d}<\mathrm{dL}$ & dependen \\
\hline $\mathrm{d} \mathrm{L}<=\mathrm{d}<=\mathrm{dU}$ & tidak ada putusan \\
\hline $\mathrm{d} \mathrm{U}<=\mathrm{d}<=4-\mathrm{dU}$ & tidak dependen \\
\hline $4-\mathrm{d} \mathrm{U}<=\mathrm{d}<=4-\mathrm{dL}$ & tidak ada putusan \\
\hline $4-\mathrm{dL}<=\mathrm{d}<=4$ & dependen \\
\hline
\end{tabular}

Untuk mengetahui residual memenuhi asumsi identik maka dapat dilakukan uji Breusch-Pagan sebagai berikut:

$H_{0}$ : error identik (bebas kasus heteroskedastisitas)

$H_{1}$ : error tidak memenuhi asumsi identik (terjadi kasus heteroskedastisitas)

Statistik uji: Error memenuhi asumsi identik apabila nilai $p$-value lebih dari $\alpha$.

Menurut Daniel [13] Pengujian normalitas error dapat digunakan uji Kolmogorov-Smirnov.

$\mathrm{H}_{0}$ : error berdistribusi normal.

$\mathrm{H}_{1}$ : error tidak berdistribusi normal.

Statistik Uji:

$$
D=\operatorname{Sup}_{\varepsilon}\left|S(\varepsilon)-F_{0}(\varepsilon)\right|
$$

dengan

$S(\mathcal{E}) \quad=$ fungsi peluang kumulatif

$F_{0}(\mathcal{E})$ = fungsi peluang kumulatif distribusi normal atau fungsi distribusi yang dihipotesiskan

$F(\varepsilon)$ = fungsi distribusi yang belum diketahui

Sup $=$ nilai supremum semua $\varepsilon$ dari $\left|S(\varepsilon)-F_{0}(\varepsilon)\right|$.

Daerah Kritis :

Jika D $>D_{l-\alpha, n}$ dapat disimpulkan bahwa error berdistribusi normal. 
d. Apabila kondisi a, b, c terpernuhi, maka dapat dilakukan pemodelan regresi spasial. Langkah awal pemodelan spasial yaitu melihat efek spasial terhadap model menggunakan uji Moran'I persamaan (9). Pada Persamaan (9) terdapat matriks W. Matriks W merupakan bentuk normalitas dari matrik $\mathbf{W}_{\text {Queen }}$ pada Tabel 3. Untuk mendapat $\mathbf{W}$ yaitu dengan membagi setiap elemen matrik dengan total setiap elemen baris matrik. Persamaan Moran' I yaitu sebagai berikut [14]:

$$
I=\frac{e, W e}{e^{\prime} e},
$$

dengan

$$
e=\text { vektor dari } e_{i}, e_{i}=Y_{i}-\frac{1}{n} \sum_{i=1}^{n} Y_{i}
$$

Nilai I berkisar antara -1 hingga 1 . Apabila nilai $\mathrm{I}<E(I)$ maka terjadi dependensi negatif dan sebaliknya apabila nilai $\mathrm{I}>E(I)$ terjadi nilai dependensi positif. Untuk $E(I)$ dapat dicari dengan persamaan berikut:

$$
E(I)=-\frac{1}{n-1},
$$

\begin{tabular}{|c|c|c|c|c|c|c|c|c|c|c|c|c|c|c|c|c|c|c|c|c|c|c|c|c|c|c|c|c|c|c|c|c|c|c|}
\hline & 1 & 2 & 3 & 4 & 5 & 6 & 7 & 8 & 9 & 10 & 11 & 12 & 13 & 14 & 15 & 16 & 17 & 18 & 19 & 20 & 21 & 22 & 23 & 24 & 25 & 26 & 27 & 28 & 29 & 30 & 31 & 32 & 33 & 34 \\
\hline 1 & 0 & 0 & 0 & 0 & 0 & 0 & 0 & 0 & 0 & 0 & 0 & 0 & 0 & 0 & 0 & 0 & 0 & 0 & 0 & 0 & 0 & 0 & 0 & 0 & 0 & 0 & 0 & 0 & 0 & 0 & 0 & 0 & 1 & 0 \\
\hline 2 & 0 & 0 & 0 & 0 & 0 & 0 & 0 & 0 & 0 & 0 & 0 & 0 & 0 & 0 & 0 & 0 & 0 & 0 & 0 & 0 & 0 & 0 & 0 & 0 & 0 & 0 & 0 & 0 & 0 & 0 & 0 & 0 & 0 & 0 \\
\hline 3 & 0 & 0 & 0 & 0 & 0 & 0 & 0 & 0 & 0 & 0 & 0 & 0 & 0 & 0 & 0 & 0 & 0 & 0 & 0 & 0 & 0 & 0 & 0 & 0 & 0 & 0 & 0 & 0 & 0 & 0 & 0 & 0 & 0 & 0 \\
\hline 4 & 0 & 0 & 0 & 0 & 0 & 0 & 0 & 1 & 0 & 1 & 0 & 0 & 0 & 0 & 0 & 0 & 0 & 0 & 0 & 0 & 0 & 0 & 0 & 0 & 0 & 0 & 0 & 0 & 0 & 0 & 0 & 0 & 0 & 0 \\
\hline 5 & 0 & 0 & 0 & 0 & 0 & 0 & 0 & 0 & 1 & 0 & 0 & 0 & 0 & 0 & 0 & 0 & 0 & 0 & 1 & 0 & 0 & 0 & 0 & 0 & 0 & 0 & 0 & 0 & 0 & 0 & 1 & 1 & 0 & 0 \\
\hline 6 & 0 & 0 & 0 & 0 & 0 & 0 & 0 & 0 & 0 & 0 & 0 & 0 & 0 & 0 & 0 & 0 & 0 & 0 & 0 & 0 & 0 & 0 & 0 & 0 & 0 & 0 & 0 & 1 & 0 & 1 & 0 & 0 & 0 & 0 \\
\hline 7 & 0 & 0 & 0 & 0 & 0 & 0 & 0 & 0 & 0 & 0 & 0 & 0 & 0 & 0 & 0 & 0 & 0 & 0 & 0 & 0 & 0 & 0 & 0 & 1 & 0 & 0 & 0 & 0 & 0 & 0 & 0 & 0 & 0 & 0 \\
\hline 8 & 0 & 0 & 0 & 1 & 0 & 0 & 0 & 0 & 0 & 1 & 0 & 0 & 0 & 0 & 0 & 0 & 0 & 0 & 0 & 0 & 0 & 0 & 0 & 0 & 0 & 0 & 0 & 0 & 0 & 0 & 0 & 0 & 0 & 0 \\
\hline 9 & 0 & 0 & 0 & 0 & 1 & 0 & 0 & 0 & 0 & 0 & 0 & 0 & 0 & 0 & 0 & 0 & 0 & 0 & 0 & 0 & 0 & 0 & 0 & 0 & 1 & 0 & 0 & 0 & 0 & 0 & 1 & 1 & 0 & 0 \\
\hline 10 & 0 & 0 & 0 & 1 & 0 & 0 & 0 & 1 & 0 & 0 & 1 & 0 & 0 & 0 & 0 & 0 & 0 & 0 & 0 & 0 & 0 & 0 & 0 & 0 & 0 & 0 & 0 & 0 & 0 & 0 & 0 & 0 & 0 & 0 \\
\hline 11 & 0 & 0 & 0 & 0 & 0 & 0 & 0 & 0 & 0 & 1 & 0 & 1 & 0 & 0 & 0 & 0 & 0 & 0 & 0 & 0 & 0 & 0 & 0 & 0 & 0 & 0 & 0 & 0 & 0 & 0 & 0 & 0 & 0 & 1 \\
\hline 12 & 0 & 0 & 0 & 0 & 0 & 0 & 0 & 0 & 0 & 0 & 1 & 0 & 0 & 0 & 0 & 0 & 0 & 0 & 0 & 0 & 0 & 0 & 0 & 0 & 0 & 0 & 0 & 0 & 0 & 0 & 0 & 0 & 0 & 0 \\
\hline 13 & 0 & 0 & 0 & 0 & 0 & 0 & 0 & 0 & 0 & 0 & 0 & 0 & 0 & 0 & 1 & 1 & 0 & 0 & 0 & 0 & 0 & 0 & 0 & 0 & 0 & 0 & 0 & 0 & 0 & 0 & 0 & 0 & 0 & 0 \\
\hline 14 & 0 & 0 & 0 & 0 & 0 & 0 & 0 & 0 & 0 & 0 & 0 & 0 & 0 & 0 & 1 & 1 & 0 & 0 & 0 & 0 & 0 & 0 & 0 & 0 & 0 & 0 & 0 & 0 & 0 & 0 & 0 & 0 & 0 & 0 \\
\hline 15 & 0 & 0 & 0 & 0 & 0 & 0 & 0 & 0 & 0 & 0 & 0 & 0 & 1 & 1 & 0 & 1 & 0 & 0 & 0 & 0 & 0 & 0 & 0 & 0 & 0 & 0 & 0 & 0 & 0 & 0 & 0 & 0 & 0 & 0 \\
\hline 16 & 0 & 0 & 0 & 0 & 0 & 0 & 0 & 0 & 0 & 0 & 0 & 0 & 1 & 1 & 1 & 0 & 1 & 0 & 0 & 0 & 0 & 0 & 0 & 0 & 0 & 0 & 0 & 0 & 0 & 0 & 0 & 0 & 0 & 0 \\
\hline 17 & 0 & 0 & 0 & 0 & 0 & 0 & 0 & 0 & 0 & 0 & 0 & 0 & 0 & 0 & 0 & 1 & 0 & 0 & 0 & 0 & 0 & 0 & 0 & 0 & 0 & 0 & 0 & 0 & 0 & 0 & 0 & 0 & 0 & 0 \\
\hline 18 & 0 & 0 & 0 & 0 & 0 & 0 & 0 & 0 & 0 & 0 & 0 & 0 & 0 & 0 & 0 & 0 & 0 & 0 & 0 & 0 & 0 & 0 & 0 & 0 & 0 & 0 & 0 & 0 & 0 & 0 & 0 & 0 & 0 & 0 \\
\hline 19 & 0 & 0 & 0 & 0 & 1 & 0 & 0 & 0 & 0 & 0 & 0 & 0 & 0 & 0 & 0 & 0 & 0 & 0 & 0 & 0 & 0 & 0 & 0 & 0 & 0 & 0 & 0 & 0 & 0 & 0 & 0 & 1 & 0 & 0 \\
\hline 20 & 0 & 0 & 0 & 0 & 0 & 0 & 0 & 0 & 0 & 0 & 0 & 0 & 0 & 0 & 0 & 0 & 0 & 0 & 0 & 0 & 0 & 0 & 0 & 0 & 0 & 0 & 0 & 0 & 0 & 0 & 0 & 0 & 0 & 0 \\
\hline 21 & 0 & 0 & 0 & 0 & 0 & 0 & 0 & 0 & 0 & 0 & 0 & 0 & 0 & 0 & 0 & 0 & 0 & 0 & 0 & 0 & 0 & 0 & 0 & 0 & 0 & 0 & 0 & 0 & 0 & 0 & 0 & 0 & 0 & 0 \\
\hline 22 & 0 & 0 & 0 & 0 & 0 & 0 & 0 & 0 & 0 & 0 & 0 & 0 & 0 & 0 & 0 & 0 & 0 & 0 & 0 & 0 & 0 & 0 & 0 & 0 & 0 & 0 & 0 & 0 & 0 & 0 & 0 & 0 & 0 & 0 \\
\hline 23 & 0 & 0 & 0 & 0 & 0 & 0 & 0 & 0 & 0 & 0 & 0 & 0 & 0 & 0 & 0 & 0 & 0 & 0 & 0 & 0 & 0 & 0 & 0 & 0 & 0 & 0 & 0 & 0 & 0 & 0 & 0 & 0 & 0 & 0 \\
\hline 24 & 0 & 0 & 0 & 0 & 0 & 0 & 1 & 0 & 0 & 0 & 0 & 0 & 0 & 0 & 0 & 0 & 0 & 0 & 0 & 0 & 0 & 0 & 0 & 0 & 0 & 0 & 0 & 0 & 0 & 0 & 0 & 0 & 0 & 0 \\
\hline 25 & 0 & 0 & 0 & 0 & 0 & 0 & 0 & 0 & 1 & 0 & 0 & 0 & 0 & 0 & 0 & 0 & 0 & 0 & 0 & 0 & 0 & 0 & 0 & 0 & 0 & 0 & 0 & 0 & 0 & 0 & 1 & 0 & 1 & 0 \\
\hline 26 & 0 & 0 & 0 & 0 & 0 & 0 & 0 & 0 & 0 & 0 & 0 & 0 & 0 & 0 & 0 & 0 & 0 & 0 & 0 & 0 & 0 & 0 & 0 & 0 & 0 & 0 & 1 & 1 & 0 & 0 & 0 & 0 & 0 & 0 \\
\hline 27 & 0 & 0 & 0 & 0 & 0 & 0 & 0 & 0 & 0 & 0 & 0 & 0 & 0 & 0 & 0 & 0 & 0 & 0 & 0 & 0 & 0 & 0 & 0 & 0 & 0 & 1 & 0 & 1 & 1 & 0 & 0 & 0 & 0 & 0 \\
\hline 28 & 0 & 0 & 0 & 0 & 0 & 1 & 0 & 0 & 0 & 0 & 0 & 0 & 0 & 0 & 0 & 0 & 0 & 0 & 0 & 0 & 0 & 0 & 0 & 0 & 0 & 1 & 1 & 0 & 1 & 0 & 0 & 0 & 0 & 0 \\
\hline 29 & 0 & 0 & 0 & 0 & 0 & 0 & 0 & 0 & 0 & 0 & 0 & 0 & 0 & 0 & 0 & 0 & 0 & 0 & 0 & 0 & 0 & 0 & 0 & 0 & 0 & 0 & 1 & 1 & 0 & 0 & 0 & 0 & 0 & 0 \\
\hline 30 & 0 & 0 & 0 & 0 & 0 & 1 & 0 & 0 & 0 & 0 & 0 & 0 & 0 & 0 & 0 & 0 & 0 & 0 & 0 & 0 & 0 & 0 & 0 & 0 & 0 & 0 & 0 & 0 & 0 & 0 & 0 & 0 & 0 & 0 \\
\hline 31 & 0 & 0 & 0 & 0 & 1 & 0 & 0 & 0 & 1 & 0 & 0 & 0 & 0 & 0 & 0 & 0 & 0 & 0 & 0 & 0 & 0 & 0 & 0 & 0 & 1 & 0 & 0 & 0 & 0 & 0 & 0 & 0 & 1 & 0 \\
\hline 32 & 0 & 0 & 0 & 0 & 1 & 0 & 0 & 0 & 1 & 0 & 0 & 0 & 0 & 0 & 0 & 0 & 0 & 0 & 1 & 0 & 0 & 0 & 0 & 0 & 0 & 0 & 0 & 0 & 0 & 0 & 0 & 0 & 0 & 0 \\
\hline 33 & 1 & 0 & 0 & 0 & 0 & 0 & 0 & 0 & 0 & 0 & 0 & 0 & 0 & 0 & 0 & 0 & 0 & 0 & 0 & 0 & 0 & 0 & 0 & 0 & 1 & 0 & 0 & 0 & 0 & 0 & 1 & 0 & 0 & 0 \\
\hline 34 & 0 & 0 & 0 & 0 & 0 & 0 & 0 & 0 & 0 & 0 & 1 & 0 & 0 & 0 & 0 & 0 & 0 & 0 & 0 & 0 & 0 & 0 & 0 & 0 & 0 & 0 & 0 & 0 & 0 & 0 & 0 & 0 & 0 & 0 \\
\hline
\end{tabular}

apabila $I=E(I)$ artinya tidak terdapat autokorelasi spasial.

Tabel 3. Matrik Pembobot

Tabel 3 merupakan matrik pembobot yang digunakan di dalam penelitian ini. Pembobotan tersebut menggunakan pendekatan Queen contiguity (persinggungan sisi-sudut). Sebagai contoh yaitu angka 8 merupakan simbol penomoran untuk Provinsi DKI Jakarta (untuk penomoran provinsi lainnya bisa lihat pada Tabel 1). Kondisi geografi Provinsi DKI Jakarta berbatasan langsung dengan Provinsi Banten (no. 4) dan Jawa Barat (no. 10), sehingga untuk kedua provinsi tersebut pada baris no 8 diberikan angka 1 dan untuk provinsi lainnya diberikan angka 0 . Begitu seterusnya untuk semua provinsi sehingga diperoleh matrik pembobot $\mathbf{W}_{\text {Queen }}$ pada Tabel 3.

e. Langkah selanjutnya yaitu menentukan regresi spasial: Spatial Autoregressive Model (SAR), Spatial Error Model (SEM), atau Spatial Autoregressive Moving Average (SARMA) menggunakan uji Lagrange Multiplier. Menurut Anselin untuk menentukan model yang terbaik dalam pembentukan model regresi spasial dapat digunakan hasil uji Lagrange Multiplier paling signifikan. Untuk uji hipotesis dari ketiga model tersebut yaitu [15]:
i. Model SAR
$\mathrm{H}_{0}: \lambda=0$
$\mathrm{H}_{1}: \lambda \neq 0$
ii. Model SEM 


$$
\begin{aligned}
& \mathrm{H}_{0}: \rho=0 \\
& \mathrm{H}_{1}: \rho \neq 0 \\
\text { iii. } & \text { Model SARMA } \\
& \mathrm{H}_{0}: \lambda \text { dan } \rho=0 \\
& \mathrm{H}_{1}: \lambda \text { dan } \rho \neq 0
\end{aligned}
$$

dengan,

$\rho=$ matriks koefisien parameter spasial lag variabel prediktor

$\lambda=$ matriks koefisien parameter spasial lag pada error.

Statistik uji yang digunakan yaitu:

i. SAR

ii. SEM

$$
\begin{aligned}
& L M=\left[\frac{\varepsilon, \boldsymbol{W} \varepsilon}{\sigma^{2}}\right]\left[\boldsymbol{T}_{22}-\left(\boldsymbol{T}_{21}\right)^{2} \operatorname{var}(\sigma)\right]^{-1} \sim \chi_{(1)}^{2} \\
& \boldsymbol{T}_{\mathbf{2 2}}=\operatorname{trace}\left(\boldsymbol{W} . * \boldsymbol{W}+\boldsymbol{W}^{\prime} \boldsymbol{W}\right) \\
& \boldsymbol{T}_{\mathbf{2 1}}=\operatorname{trace}\left(\boldsymbol{W} \cdot \boldsymbol{C} \boldsymbol{A}^{-\mathbf{1}}+W^{\prime} C A^{-1}\right) \\
& \boldsymbol{A}=\left(\boldsymbol{I}_{\boldsymbol{n}}-\rho \boldsymbol{C}\right) \\
& \sigma^{2}=\frac{\varepsilon^{\prime} \varepsilon}{n}
\end{aligned}
$$

dengan

$$
\begin{aligned}
& L M=\left[\frac{1}{T}\right]\left[\frac{\varepsilon_{\prime} \boldsymbol{W} Y}{\sigma^{2}}\right]^{2} \sim \chi_{(1)}^{2} \\
& \boldsymbol{T}=\operatorname{trace}\left(\boldsymbol{W}+\boldsymbol{W}^{\prime}\right) . * \boldsymbol{W} \\
& \sigma^{2}=\frac{\varepsilon^{\prime} \varepsilon}{n}
\end{aligned}
$$

$\boldsymbol{C}=$ Matrik standard dari $\mathbf{W}_{\mathbf{Q u e e n}}$

*. = operasi perkalian titik pada elemen matriks

Tolak $\mathrm{H}_{0}$ apabila nilai uji Lagrange Multiplier $(\mathrm{LM})>\chi_{(1)}^{2}$, sehingga untuk menetukan model yang paling sesuai bisa juga dilihat nilai $p$-value paling signifikan. $P$-value signifikan apabila kurang dari $\alpha$.

f. Melakukan estimasi parameter regresi spasial. Setelah dilakukan estimasi parameter, maka selanjutnya dilakukan pengujian parameter apakah parameter tersebut berpengaruh signifikan terhadap model. Dikatakan signifikan apabila nilai $p$-value kurang dari alfa yang telah ditentukan. Model regresi spasial sendiri merupakan perkembangan dari model regresi linier berganda. Di dalam pemodelan regresi spasial ditambahkan pembobot yang menjadi komponen dalam model. Setiap bobot yang diberikan pada model menunjukan keterkaitan secara spasial. Berikut model dari regresi spasial:

$$
\begin{aligned}
& \boldsymbol{Y}=\rho \boldsymbol{W} \boldsymbol{Y}+\boldsymbol{X} \boldsymbol{\beta}+\boldsymbol{u} \\
& \boldsymbol{u}=\boldsymbol{\lambda} \boldsymbol{W} \boldsymbol{u}+\varepsilon
\end{aligned}
$$

dengan:

$$
\begin{array}{ll}
\rho & =\text { matriks koefisien parameter spasial lag variabel prediktor } \\
\lambda & =\text { matriks koefisien parameter spasial lag pada } \text { error } \\
\boldsymbol{W} & =\text { matriks pembobot spasial } \\
\boldsymbol{u}, \mathcal{E} & =\text { vektor } \text { error }
\end{array}
$$

Seperti pada model regresi linier berganda untuk estimasi parameter regresi spasial dapat dicari dengan menggunakan metode least square. Untuk estimasi parameter Persamaan (13) dapat dicari dengan Persamaan (15) [16].

$$
\widehat{\boldsymbol{\beta}}=\left(\boldsymbol{X}^{\prime} \boldsymbol{X}\right)^{-\mathbf{1}} \boldsymbol{X}^{\prime}(\boldsymbol{I}-\rho \boldsymbol{W}) \boldsymbol{Y}
$$

g. Mendapatkan nilai $\mathrm{R}^{2}$.

h. Melakukan intepretasi model.

\section{HASIL DAN PEMBAHASAN}

Pada bagian ini dideskripsikan jumlah investasi pemodalan dari luar negeri beserta variabel yang mempengaruhinya. Pemodelan regresi spasial dilakukan setelah pemodelan regresi linier berganda. 


\subsection{Karakteristik Data Penelitian}

Untuk mengetahui bagaimana karakterik jumlah investasi dari luar negeri yang masuk di Indonesia digunakan pemetaan. Gambar 1 merupakan jumlah investasi penanaman modal yang masuk di Indonesia pada tahun 2017. Berdasarkan Gambar 1 dapat dilihat provinsi yang mendapatkan investasi lebih dari 4000 juta USD yaitu DKI Jakarta dan Provinsi Jawa Barat. Untuk DKI jakarta sebesar 4595 juta USD dan Provinsi Jawa Barat sebesar 5142 juta USD. Rata-rata investasi yang masuk di provinsi di Indonesia sebesar 948,22 juta USD dengan varians sebesar 1.547.266 juta USD. Apabila dilihat dari sudut pandang pulau, maka pulau jawa merupakan pulau yang mendapatkan investasi yang besar dibandingkan pulau lainnya. Di pulau sendiri merupakan pulau yang paling maju dari segi pembangunannya dibandingkan pulau lainnya yang ada di Indonesia. Oleh sebab itu investasi luar negeri yang masuk di Pulau Jawa lebih tinggi dibandingkan pulau lainnya. Dilihat dari segi jumlah investasi luar negeri yang masuk indonesia, Provinsi Jawa Barat merupakan provinsi yang paling tinggi mendapatkan dana investasi dari luar negeri yaitu sekitar 5.142, 90 juta USD pada tahun 2017.

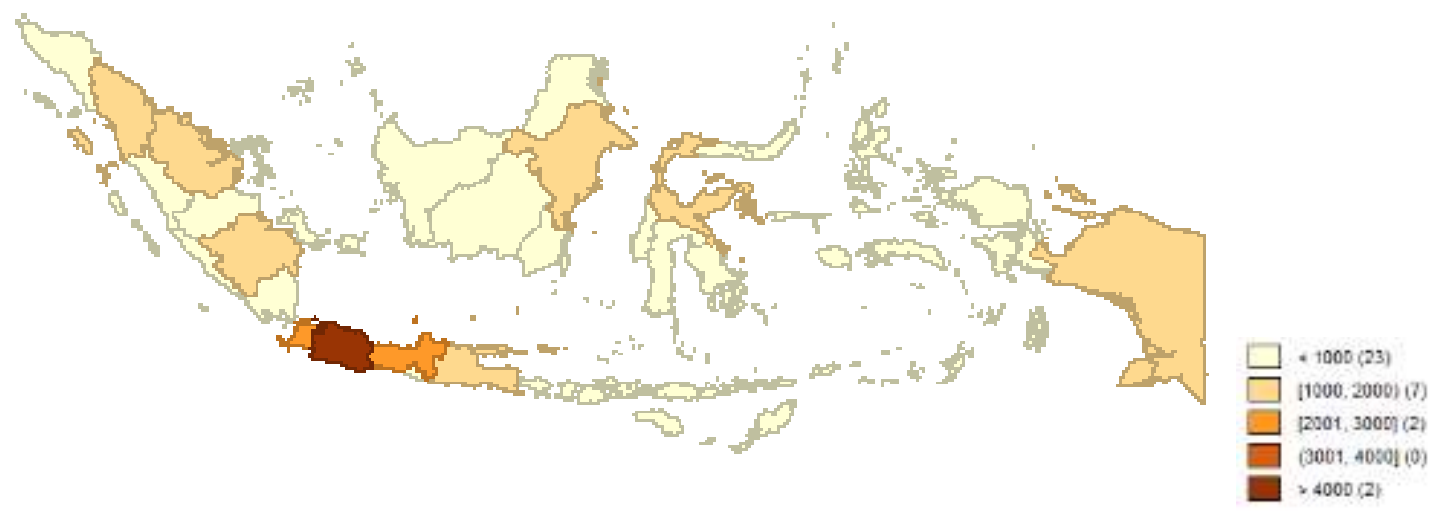

Gambar 1. Jumlah Investasi Penanaman Modal Luar Negeri 2017 Sumber Data: Data BPS yang diolah dengan Geoda

Disusul oleh Provinsi DKI Jakarta dengan angka 4.595 juta USD. Akan tetapi para investor luar negeri kurang tertarik untuk berinvestasi di luar pulau jawa. Untuk wilayah luar pulau jawa yang kurang diminati oleh investor luar negeri yaitu mayoritas di wilayah Indonesia timur. Untuk provinsi di Indonesia yang paling sedikit mendapatkan dana investasi dari luar negeri yaitu Provinsi Sulawesi Barat. Untuk Provinsi Sulawesi Barat hanya mendapatkan dana investasi luar negeri sebesar 11,40 juta USD.

Tabel 4. Statistik Deskriptif Jumlah Investasi Penanaman Modal Luar Negeri 2017

\begin{tabular}{lc}
\multicolumn{1}{c}{ Statistik } & Nominal \\
\hline Total & $32.239,60$ \\
\hline Rata-rata & 948,22 \\
\hline Maksimum & $5.142,90$ \\
\hline Minimum & 11,40 \\
\hline Varians & $1.547 .266,39$ \\
\hline
\end{tabular}

Secara total pada tahun 2017 dana investasi yang masuk di Indonesia yaitu sebesar 32.239,60 juta USD. Dana investasi dari luar negeri tersebut digunakan untuk pembangunan ekonomi nasional. Penanaman modal asing tersebut masuk ke sektor industri pelabuhan, produksi dan transmisi serta distribusi tenaga listrik umum, telekomunikasi, penerbangan, pelayaran, air minum, media masa, keuangan, pertambangan, dan lain-lainnya.

Gambar 2 menunjukkan besaran upah/gaji bersih bulanan yang ada di Indonesia. Upah/gaji bersih bulanan merupakan penerimaan buruh/karyawan berupa uang atau barang yang dibayarkan perusahaan/kantor/majikan tersebut. Penerimaan dalam bentuk barang dinilai dengan harga setempat. Penerimaan bersih yang dimaksud tersebut adalah setelah dikurangi dengan potongan-potongan iuran wajib pajak penghasilan dan lain-lain. Untuk upah/gaji bersih bulanan pada tahun 2017, rata-rata upah/gaji bersih bulanan dipulau jawa lebih kecil dibandingkan upah/gaji bersih bulanan diluar Jawa. Pada Gambar 2 menunjukan untuk Provinsi Jawa Barat dan Banten dikategorikan dengan upah/gaji bersih bulanan menengah. Untuk DKI Jakarta dikategorikan upah/gaji bersih bulanan yang tinggi. Sedangkan untuk Jawa Tengah, Yogyakarta, dan Jawa Timur dikategorikan kelompok upah/gaji bersih bulanan yang rendah. Untuk upah/gaji bersih bulanan tertinggi di Indonesia pada tahun 2017 terletak di pulau Jawa yaitu Provinsi DKI Jakarta. Untuk besar upah/gaji bersih bulanan DKI Jakarta pada tahun 2017 yaitu sebesar Rp 4.089.123,00. Kita ketahui bahwa DKI Jakarta merupakan ibukota Negara Indonesia. 


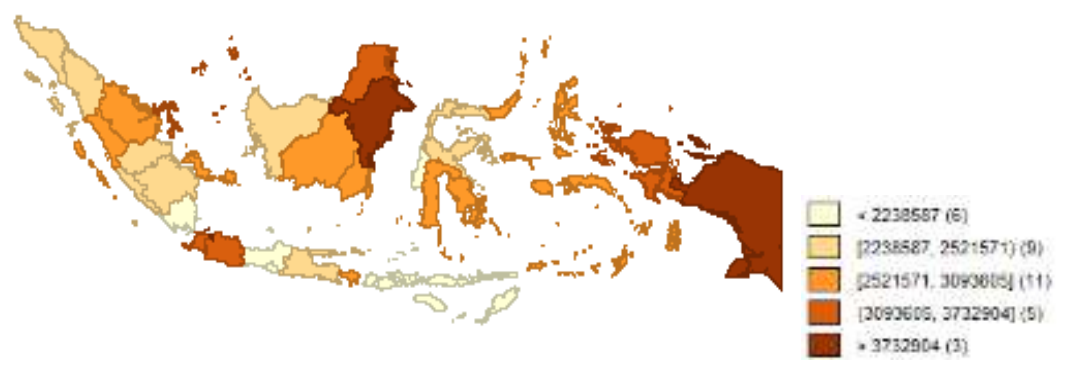

Gambar 2. Upah/Gaji Bersih Bulanan Di Indonesia 2017 Sumber Data: Data BPS yang diolah dengan Geoda

Besar upah/gaji bersih bulanan di provinsi DKI Jakarta menyesuaikan dengan biaya hidup di provinsi tersebut. Biaya hidup di Provinsi DKI Jakarta merupakan paling mahal dibandingkan dengan provinsi lainnya di Indonesia. Sehingga pekerja menuntut upah/gaji yang tinggi untuk provinsi tersebut. Gambar 2 menunjukkan bahwa besar upah/gaji bersih bulanan luar Pulau Jawa dominan lebih tinggi dibandingkan dengan pulau jawa. Faktor tingginya besar upah/gaji bersih bulanan tersebut dapat berpengaruh terhadap penanaman modal untuk masuk. Pada Gambar 1 menunjukkan investasi luar negeri yang masuk di Indonesia yang memiliki rata-rata tinggi yaitu provinsi yang berada di Pulau Jawa. Hal tersebut dikarenakan investor akan melirik provinsi yang memiliki besar upah/gaji bersih bulanan yang rendah guna untuk menekan biaya operasional.

Tabel 5. Statistik Deskriptif Besar Upah/Gaji Bersih Bulanan di Indonesia Tahun 2017

\begin{tabular}{lc}
\hline \multicolumn{1}{c}{ Statistik } & Nominal \\
\hline Rata-rata & $2.714 .403,06$ \\
\hline Maksimum & $4.089 .123,00$ \\
\hline Minimum & $2.010 .062,00$ \\
\hline Varians & $332.635 .095 .404,18$ \\
\hline
\end{tabular}

Berdasarkan Tabel 5 dapat dilihat bahwa untuk upah/gaji bersih bulanan yang paling rendah yaitu Provinsi Jawa Tengah dengan nominal sebesar Rp2.010.062,00. Di Provinsi Jawa Tengah untuk biaya hidup lebih murah dibandingkan dengan provinsi lainnya di Indonesia. Sehingga menjadikan upah/gaji bersih bulanan di Provinsi Jawa Tengah lebih rendah dibandingkan yang lainnya. Rata-rata Jawa Tengah di Indonesia pada tahu 2017 menunjukan angka 2.714.403,06. Sebanyak 14 provinsi di Indonesia yang angka UMPnya di atas rata-rata upah/gaji bersih bulanan. Hanya tiga provinsi yang terletak di Pulau Jawa untuk upah/gaji bersih bulanannya diatas rata-rata yaitu provinsi DKI Jakarta, Provinsi Jawa Barat, dan Provinsi Banten. Untuk 11 provinsi yang angka upah/gaji bersih bulanannya diatas upah/gaji bersih bulanan rata-rata provinsi terletak di luar Pulau Jawa.

Gambar 3 menunjukkan jumlah angkatan kerja di setiap provinsi tahun 2017. Jumlah angkatan kerja merupakan penduduk usia kerja dibagi menjadi dua golongan yaitu yang termasuk angkatan kerja dan yang termasuk bukan angkatan kerja. Penggolongan usia kerja di Indonesia mengikuti standar internasional yaitu usia 15 tahun atau lebih. Angkatan kerja sendiri terdiri dari mereka yang aktif bekerja dan mereka yang sedang mencari pekerjaan. Mereka yang terakhir itulah yang dinamakan sebagai pengangguran terbuka. Sedangkan yang termasuk dalam kelompok bukan angkatan kerja adalah mereka yang masih bersekolah, ibu rumah tangga, pensiunan dan lain-lain. Dilihat dari jumlah angkatan kerja di Pulau Jawa merupakan pulau yang paling banyak angkatan kerjanya dibandingkan di luar Pulau Jawa. Pulau jawa mendominasi jumlah angkatan kerja karena jumlah penduduk Jawa lebih padat dibandingkan pulau lain. Tersedianya tenaga kerja merupakan salah satu seorang investor untuk memberikan modal usahanya. Pada Gambar 1 investor luar nergeri yang masuk Indonesia yang tinggi rata-rata terdapat di provinsi yang berada di Pulau Jawa. Didukung pendidikan yang lebih memadai maka investor akan lebih tertarik lagi. Kita ketahui bahwa pendidikan di Pulau Jawa lebih bagus dibandingkan pendidikan di luar Pulau Jawa. Sebagai bukti kita dapat melihat banyaknya perguruan tinggi yang bonafit terdapat di Pulau Jawa. Jumlah angkatan kerja yang paling tinggi di Indonesia pada tahun 2017 adalah Provinsi Jawa Barat yaitu sebanyak 22.391.003 orang. Hal itu mendukung pada Gambar 1 bahwa investasi dari luar negeri yang masuk ke Indonesia pada tahun 2017 yaitu di Provinsi Jawa Barat. Seorang investor akan lebih suka dengan tenaga kerja yang tersedia lebih banyak dan mendapatkan pendidikan yang layak. Dengan adanya tenaga kerja yang banyak investor akan mendapatkan tenaga kerja yang selektif dan lebih murah. 


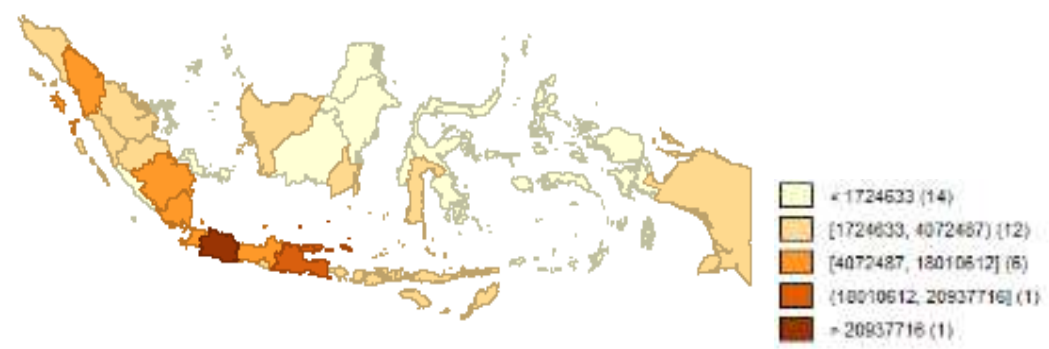

Gambar 3. Jumlah Angkatan Kerja Yang Bekerja 2017 Sumber Data: Data BPS yang diolah dengan Geoda

Berbeda dengan jumlah tenaga kerja yang berada di luar Pulau Jawa yang lebih sedikit, sehingga membuat investor tidak terlalu tertarik. Dikarenakan dengan sedikitnya jumlah tenaga kerja yang ada di lapangan maka akan membuat jumlah permintaan tenaga kerja yang tinggi. Apabila tersebut terjadi maka upah yang akan diminta oleh pekerja akan naik juga. Upah yang tinggi dapat mempengaruhi profitabilitas dari suatu perusahaan.

Tabel 6. Statistik Deskriptif Jumlah Angkatan Kerja Provinsi di Indonesia Tahun 2017

\begin{tabular}{lc}
\multicolumn{1}{c}{ Statistik } & Nominal \\
\hline Rata-rata & $3.766 .551,35$ \\
\hline Maksimum & $22.391 .003,00$ \\
\hline Minimum & $330.731,00$ \\
\hline Varians & $30.356 .822 .197 .792,50$ \\
\hline Total & $128.062 .746,00$ \\
\hline
\end{tabular}

Berdasarkan Tabel 6 kita ketahui bahwa jumlah angkatan kerja yang paling sedikit yaitu 330.731. Provinsi dengan jumlah angkatan kerja paling sedikit yaitu Kalimantan Utara. Kita ketahui bahwa di Pulau Kalimantan tersedia sumber daya alam yang luar biasa, akan tetapi SDA tersebut belum didukung oleh sumber daya manusianya. Jumlah penduduk di Provinsi Kalimantan Utara tidak terlalu padat dibandingkan dengan provinsi-provinsi yang ada di pulau Jawa. Hal ini harus menjadi perhatian bagi pemerintah agar pembangunan ekonomi di Indonesia merata. Secara nasional jumlah angkatan kerja di Indonesia pada tahun 2017 yaitu sebanyak 128.062.743 dan rata-rata untuk tenaga kerja berdasarkan provinsi yaitu 3.766.551. Kita lihat bahwa jumlah tenaga kerja Provinsi Kalimantan Utara masih jauh dibandingkan rata-rata jumlah tenaga kerja provinsi di Indonesia. Sedangkan angka jumlah tenaga kerja di Provinsi Jawa barat jauh lebih tinggi dibandingkan dengan rata-rata jumlah tenaga kerja provinsi di Indonesia

\subsection{Pemodelan Regresi Linier Berganda}

Pemodelan regresi linier berganda dilakukan sebelum pemodelan regresi spasial. Harapannya dengan terpenuhinya asumsi pada model regresi linier berganda maka pada pemodelan regresi spasial akan terpenuhi juga. Dengan momodelkan Jumlah Investasi Penanaman Modal Luar Negeri dengan Upah/Gaji Bersih Bulanan dan Jumlah Angkatan Kerja. Dengan data tersebut diperoleh model dengan variabel Upah/Gaji Bersih Bulanan dan Jumlah Angkatan Kerja berpengaruh signifikan terhadap Jumlah Investasi Penanaman Modal Luar Negeri. Akan tetapi model tersebut tidak memenuhi 1 asumsi klasik yaitu asumsi error terjadi kasus heteroskedastisitas. Untuk memenuhi asumsi klasik yang menjadi syarat dari pemodelan regresi linier berganda, maka dilakukan transformasi data. Transformasi yang digunakan yaitu transformasi Ln (logaritma natural). Jadi untuk variabel prediktor maupun variabel respon dilakukan transformasi Ln. Berikut hasil estimasi parameter dari model regresi.

Tabel 7. Pemodelan Regresi Linier Berganda

\begin{tabular}{lrrrr}
\hline \multicolumn{1}{c}{ Variabel } & Koefisien & Standard Error & P-value & VIF \\
\hline Konstanta & $-74,860$ & 12,154 & 0,000 & \\
\hline Upah/Gaji Bersih Bulanan & 4,504 & 0,791 & 0,000 & 1,013 \\
\hline Jumlah Angkatan Kerja & 0,975 & 0,150 & 0,000 & 1,013 \\
\hline
\end{tabular}

Pada Tabel 7 didapatkan nilai $p$-value bernilai 0,000 untuk semua parameter. Angka $p$-value tersebut menunjukan bahwa semua variabel prediktor berpengaruh signifikan terhadap model. Angka VIF yang diperoleh dari model tersebut juga kecil yaitu 1,013 yang bisa dikatakan bahwa pada kasus tersebut tidak ada kasus multikolinieritas. Tahap selanjutnya yaitu melakukan uji asumsi terhadap error dari model yang harus memenuhi asumsi IIDN. Berdasarkan error dari model diperoleh nilai uji Kolmogorov Smirnov (D) sebesar 
0,475 dengan $p$-value sebesar 0,978. Sehingga dapat disimpulkan bahwa error telah mengikuti distribusi normal dengan taraf $\alpha=5 \%$. Untuk angka Durbin Watson $(d)$ diperoleh nilai sebesar 1,859. Dengan $\mathrm{n}=34$ dan $\mathrm{k}=2$, maka diperoleh $\mathrm{dL}=1,333$ dan $\mathrm{dU}=1,581$ dengan taraf $\alpha=5 \%$. Sehingga nilai $\mathrm{dU}<\mathrm{d}<4-\mathrm{dU}$, dapat dikatakan bahwa error independen atau tidak ada kasus autokorelasi. Untuk selanjutnya yaitu melihat asumsi identik pada error. Berdasarkan hasil uji uji Breusch-Pagan diperoleh nilai sebesar 4,2637 dan $p$ value sebesar $0,11862>5 \%$ yang artinya tidak terjadi kasus heteroskedastisitas. Perlu diketahui dengan pemodelan regresi linier berganda diperoleh nilai $R^{2}$ sebesar 0,68 .

\subsection{Pemodelan Regresi Spasial}

Pada tahap pemodelan pada regresi spasial digunakan data yang sudah ditransformasi Ln. Dikarenakan model regresi linier berganda yang sesuai pada penelitian ini menggunakan data yang sudah ditransformasi Ln. Untuk pengolahan data digunakan batuan software Geoda. Untuk mengetahui efek spasial setiap variabel penelitian dilakukan perhitungan nilai Moran's I. Rumus perhitungan menggunakan Persamaan (9). Berikut hasil perhitungannya:

Tabel 8. Nilai Moran's I Masing-Masing Variabel

\begin{tabular}{lc}
\hline \multicolumn{1}{c}{ Variabel } & Moran's I \\
\hline Jumlah Investasi Penanaman Modal Luar Negeri & $-0,063$ \\
\hline Upah/Gaji Bersih Bulanan & 0,597 \\
\hline Jumlah Angkatan Kerja & 0,524 \\
\hline
\end{tabular}

Hasil perhitungan $E(I)=I_{0}$ diperoleh angka -0,033. Berdasarkan Tabel 8 dapat disimpulkan bahwa variabel prediktor memiliki dependensi (autokorelasi) yang positif, sedangkan untuk variabel prediktor memiliki dependesi (autokoralasi) negatif.

Untuk selanjutnya yaitu melakukan uji Lagrange Multiplier (LM). Tujuan uji tersebut yaitu digunakan untuk mengetahui apakah data layak dimodelkan menggunakan regresi spasial dan untuk menentukan model spasial yang sesuai yaitu apakah Spatial Autoregressive Model (SAR), Spatial Error Model (SEM), atau Mixture (SARMA). Berikut hasil uji Lagrange Multiplier dari data penelitian.

Tabel 9. Uji Lagrange Multiplier

\begin{tabular}{lcc}
\hline Uji Lagrange & Nilai & $P$-value \\
\hline SAR & 42,370 & 0,03955 \\
\hline SEM & 32,708 & 0,07052 \\
\hline SARMA & 58,446 & 0,05381 \\
\hline
\end{tabular}

Tabel 9 menunjukkan hasil uji Lagrange Multiplier. Berdasarkan uji tersebut SAR mempunyai $p$-value $<\alpha=$ $5 \%$, sedangkan SEM dan SARMA mempunyai $p$-value $>\alpha=5 \%$. Artinya bahwa data penelitian dapat dimodelkan dengan model regresi spasial dan model yang paling sesuai yaitu SAR. Berikut adalah model regresi spasial untuk data penelitian.

Tabel 10. Pemodelan Regresi Spasial

\begin{tabular}{lrrr}
\hline \multicolumn{1}{c}{ Variabel } & Koefisien & Standard Error & $P$-value \\
\hline Pembobot Spasial ( $\mathrm{Lag})$ & $-0,1096$ & 0,053 & 0,039 \\
\hline Konstanta & $-78,55$ & 11,157 & 0,000 \\
\hline Upah/Gaji Bersih Bulanan & 4,697 & 0,721 & 0,000 \\
\hline Jumlah Angkatan Kerja & 1,072 & 0,143 & 0,000 \\
\hline
\end{tabular}

Dapat dilihat pada Tabel 10 dengan pemodelan spasial bahwa untuk variabel Upah/Gaji Bersih Bulanan, Jumlah Angkatan Kerja, dan Pembobot Spasial (Lag) berpengaruh signifikan terhadap model yang terbentuk. Untuk kita ketahui model tersebut merupakan model yang dibentuk dengan data yang sudah ditransformasi Ln.

Dari model regresi spasial tersebut dapat dimodelkan untuk masing-masing provinsi. Artinya pada penelitian ini diperoleh 34 model regresi spasial untuk masing-masing provinsi. Sebagai contoh diberikan model untuk Provinsi DKI Jakarta. Pada Tabel 1 struktur data penelitian, Provinsi DKI Jakarta merupakan observasi ke 8. Kita ketahui bahwa Provinsi DKI Jakarta bertetanggaan atau memiliki perbatasan langsung dengan Provinsi Jawa Barat (observasi ke 10) dan Provinsi Banten (observasi ke 4). Sehingga untuk kedua provinsi tersebut kita berikan pembobot 1 , dimana pemberian pembobot untuk seluruh provinsi dapat dilihat pada Tabel 3 matriks pembobot. Setelah itu jumlahkan elemen matrik setiap barisnya. Setelah didapatkan penjumlahan elemen matriks baris, maka selanjutnya membuat matrik pembobot yang telah dinormalitaskan 
(setiap elemen matriks dibagi oleh penjumlahan elemen matrik barisnya). Selanjutnya kalikan matriks yang telah dinormalitaskan dengan matriks $\mathrm{Y}$ yang merupakan kumpulan variabel respon penelitian. Berikut adalah model regresi spasial untuk Provinsi DKI Jakarta:

$$
\operatorname{Ln}\left(Y_{8}\right)=-78,55-0,1096\left(0,5 \operatorname{Ln}\left(Y_{4}\right)+0,5 \operatorname{Ln}\left(Y_{10}\right)\right)+4,697 \operatorname{Ln}\left(X_{1,8}\right)+1,072 \operatorname{Ln}\left(X_{2,8}\right)+\varepsilon_{8} .
$$

Dimana $Y_{8}$ merupakan Jumlah Investasi Penanaman Modal Luar Negeri di DKI Jakarta, $Y_{4}$ merupakan Jumlah Investasi Penanaman Modal Luar Negeri di Banten, $Y_{10}$ merupakan Jumlah Investasi Penanaman Modal Luar Negeri di Jawa Barat, $X_{1,8}$ merupakan Upah/Gaji Bersih Bulanan untuk DKI Jakarta, $X_{2,8}$ merupakan Jumlah Angkatan Kerja untuk DKI Jakarta, dan $\varepsilon_{8}$ merupakan error untuk model DKI Jakarta. Secara umum model regresi spasial untuk seluruh provinsi yang ada di Indonesia dapat dituliskan sebagai berikut:

$$
\operatorname{Ln}\left(Y_{i}\right)=-78,55-0,1096\left(\sum_{j-1, i \neq j}^{n} W_{i j} \operatorname{Ln}\left(Y_{j}\right)\right)+4,697 \operatorname{Ln}\left(X_{1, i}\right)+1,072 \operatorname{Ln}\left(X_{2, i}\right)+\varepsilon_{i} .
$$

Dimana $Y_{i}$ merupakan Jumlah Investasi Penanaman Modal Luar Negeri observasi ke-i (baris ke-i), $Y_{j}$ merupakan Jumlah Investasi Penanaman Modal Luar Negeri kolom ke-j, $X_{1, i}$ merupakan Upah/Gaji Bersih Bulanan observasi ke-i, dan $X_{2, i}$ merupakan Jumlah Angkatan Kerja observasi ke-i (untuk ilustrasi baris kei dan kolom ke-j bisa dilihat Tabel 3).

\subsection{Perbandingan Model Regresi Linier Berganda dan Regresi Spasial}

Salah satu indikator untuk mengatuhi kebaikan model yang terbentuk pada model regresi yaitu bisa dilihat nilai $R^{2}$. Semakin tinggi nilai $R^{2}$ maka dapat dikatakan model regresi semakin baik. $R^{2}$ sendiri digunakan untuk mengetahui seberapa besar variabel prediktor dapat menjelaskan model.

Tabel 11. Perbandingan Nilai $R^{2}$

\begin{tabular}{lc}
\hline \multicolumn{1}{c}{ Model } & $R^{2}$ \\
\hline Regresi Linier Beganda & 0,68 \\
\hline Regresi Spasial (SAR) & 0,72 \\
\hline
\end{tabular}

Untuk model regresi linier berganda diperoleh nilai $R^{2}$ sebesar 0,68 sedangkan untuk model regresi spasial diperoleh nilai $R^{2}$ sebesar 0,72 . Sehingga dapat disimpulan bahwa model regresi spasial yang diperoleh dapat dikatakan lebih baik dibandingkan dengan model regresi linier berganda.

\section{KESIMPULAN}

Berikut adalah kesimpulan dari hasil analisis dan pembahasan penelitian yang telah dilakukan:

1. Berdasarkan hasil uji Lagrange Multiplier yang menunjukan SAR signifikan dengan nilai $p$-value $<\alpha=$ $5 \%$. Artinya bahwa untuk jumlah angkatan kerja, besar upah/gaji bersih bulanan, dan jumlah investasi pemodalan luar negeri antar provinsi di Indonesia terdapat dependensi spasial antar provinsi.

2. Berdasarkan model regresi spasial (SAR) yang diperoleh menunjukan bahwa jumlah angkatan kerja, besar upah/gaji bersih bulanan, dan pembobot wilayah berpengaruh signifikan terhadap jumlah investasi pemodalan luar negeri antar provinsi di Indonesia.

\section{UCAPAN TERIMA KASIH}

Penulis mengucapkan terimakasih banyak kepada Badan Pusat Statistik yang telah menyediakan data penelitian dan Sekolah Tinggi Ilmu Ekonomi (STIESIA) Surabaya yang telah memberikan fasilitas untuk penulisan penelitian ini. 


\section{DAFTAR PUSTAKA}

[1] Badan Pusat Statistik, "Realisasi Investasi Penanaman Modal Luar Negeri Menurut Provinsi", BPS.go.id, 13 Februari 2019, [Online]. Tersedia di: https://www.bps.go.id/dynamictable/2020/05/06/1806/realisasi-investasipenanaman-modal-luar-negeri-menurut-provinsi.html [Diakses 1 September 2019].

[2] Badan Pusat Statistik, "Penduduk Berumur 15 Tahun Ke Atas Menurut Provinsi dan Jenis Kegiatan Selama Seminggu yang Lalu, 2008 - 2019”, BPS.go.id, 13 Februari 2019, [Online]. Tersedia di: https://www.bps.go.id/statictable/2016/04/04/1907/penduduk-berumur-15-tahun-ke-atas-menurut-provinsi-danjenis-kegiatan-selama-seminggu-yang-lalu-2008---2019.html [Diakses 1 September 2019].

[3] S. Sukirno, Makroekonomi Modern, Jakarta: PT RajaGrafindo Persada, 2000.

[4] I. Ambarsari dan D. Purnomo, "Studi Tentang Penanaman Modal Asing di Indonesia", Jurnal Ekonomi Pembangunan, vol. 6, no. 1, pp. 26-47, Juni 2005.

[5] P. K. Dewi dan N. Triaryati, "Pengaruh Pertumbuhan Ekonomi, Suku Bunga Dan Pajak Terhadap Investasi Asing Langsung", E-Jurnal Managemen Unud, vol. 4, no. 4, pp. 866-878, 2015.

[6] L. Anselin, I. Sabri, and Y. Kho, Geoda: An Introduction to Spatial Data Analysis, Ohio: The Ohio State University, 2006.

[7] R. E. Walpole, R. H. Myers, S. L. Myers, and K. Ye, Probability \& Statistics for engineers \& scientist, Ninth Edition, Boston: Pearson Education, 2011.

[8] Widyawati dan Setiawan, "Analisis Faktor-Faktor yang Mempengaruhi Tingkat Produksi Padi dan Jagung di Kabupaten Lamongan”, Jurnal Sains Dan Seni ITS, vol. 4, no. 1, pp. 103-108, 2015.

[9] N. R. Draper and H. Smith, .Applied Regression Analysis, New York: John Wiley \& Sons, Inc, 1998.

[10] S. C. Wohon, D. Hatidja, dan N. Nainggolan, "Penentuan Model Regresi Terbaik Dengan Menggunakan Metode Stepwise (Studi Kasus: Impor Beras Di Sulawesi Utara)”, Jurnal Ilmiah Sains, vol. 17, no. 2, pp. 80-88, Oktober 2017.

[11] R. J. Pratama, Syafi'i, dan Legowo, "Analisis Pemodelan Tarikan Pergerakan Bank Dengan Metode Analisis Regresi Linear Berganda (Studi Kasus di Wilayah Surakarta)”, E-Jurnal Matriks Teknik Sipil, vol. 1, no. 4, pp. 8$15,2013$.

[12] E. Supriyadi, S. Mariani, dan Sugiman, "Perbandingan Metode Partial Least Square (PLS) Dan Principal Component Regression (PCR) Untuk Mengatasi Multikolinearitas Pada Model Regresi Linear Berganda”, UNNES Journal of Mathematics, vol. 6, no. 2, pp. 117-128, 2017.

[13] N. Lestari dan N. Wahyuningsih, "Peramalan Kunjungan Wisata dengan Pendekatan Model SARIMA (Studi kasus: Kusuma Agrowisata)", Jurnal Sains Dan Seni ITS, vol. 1, no. 1, pp. 29-33, 2012.

[14] A. J. Lembo, Spatial Autocorrelation, Ithaca: Cornell University, 2006.

[15] R. D. K. Astuti, H. Yasin, dan Sugito, "Aplikasi Model Regresi Spasial Untuk Pemodelan Angka Partisipasi Murni Jenjang Pendidikan SMA Sederajat di Provinsi Jawa Tengah”, Jurnal Gaussian, vol. 2, no. 4, pp. 375-384, 2013.

[16] M. Rati, E. Nababan, dan Sutarman, "Model Regresi Spasial Untuk Anak Tidak Bersekolah Usia Kurang 15 Tahun di Kota Medan”, Jurnal Saintia Matematika, vol. 1, no. 1, pp. 87-99, 2013. 
